\title{
A Case Study of the Implementation of Alternative Psychomotor Assessment in Japanese Language Online Learning
}

\author{
Dhevi A. Hermawan ${ }^{1, *}$ Miftachul Amri ${ }^{1}$ Syamsul Sodiq ${ }^{2}$ \\ ${ }^{1,2}$ Universitas Negeri Surabaya, Indonesia \\ ${ }^{*}$ Corresponding author.Email: dhevi.20029@mhs.unesa.ac.id
}

\begin{abstract}
SMAN 10 Malang began implementing learning from home activities since the issuance of a circular from the government regarding the implementation of education policies during the Covid-19 emergency. Japanese language learning, which one of the subjects at SMAN 10 Malang, is also carried out online. With the limitations of space and distance, the problem faced by Japanese language teachers at SMAN 10 Malang was psychomotor assessment. To overcome this problem, several alternative assessment studies have been implemented to measure the psychomotor domain. This study aims to describe the application of learning assessment in the psychomotor domain in Japanese online learning at SMAN 10 Malang. The method used in this research is the descriptive qualitative method to collect primary data through review of documents and field data. The results of data analysis showed that several assessment alternatives have been implemented in the psychomotor domain in online Japanese language learning, including online practice, product and project assessments. The conclusion in this study is that the problem of psychomotor assessment in Japanese language learning in the Covid-19 emergency has been resolved through the application of several alternative assessments in the psychomotor domain.
\end{abstract}

Keywords: Assessment, Psychomotor domain, Online, Japanese learning

\section{INTRODUCTION}

Corona Virus Disease 2019 (COVID-19) was discovered in Wuhan, China, at the end of December 2019. This virus has infected rapidly and spread all over the country, including Indonesia which spreading only for about several months. For this reason, World Health Organisation (WHO) officially declared that these epidemics become a global pandemic on 11 March 2020. In Indonesia, Covid-19 affected society and communities in all areas of life. The impact of Covid-19 occurred on various sectors of life, such as social, economic, tourism and education. The Indonesian Minister of Education and Culture issued circular number 4 of 2020 on Implementation of Education Policy in Emergency during COVID-19 Spread, its content explained that the teaching-learning process is carried out at home through online learning or distance learning, and it is conducted to give students meaningful experiences.

To maintain the educational process and to participate in breaking the chain of the spread of the
Covid-19 virus, the implementation of learning must be adjusted to the social distancing policy launched by the government. Teaching and learning activities at all levels are carried out at the homes and are carried out through online media to temporarily close all levels of education. Teachers must ensure that teaching and learning activities continue even though students are at home. In this situation, many teachers have been forced to use online tools to provide their students with distance learning. Luckily, with expanding access to online learning technologies, this transition is more possible than it ever has been before. According to Wang et al, teachers should design their online courses in such a way that they meet the needs of students with diverse backgrounds, abilities and various levels of comfort with online tools [1]. However, in a quick transition, such as during an unexpected crisis, it is important for teachers to use the simplest and most accessible tools. Students should be introduced to new tools or apps one at a time with appropriate orientations

Learning innovation is a solution that needs to be designed and implemented by teachers by maximizing 
existing media such as online media. Teachers can conduct learning by using the E-Learning method, namely learning to use information and communication technology which the learning system is implemented through a computer (PC) or laptop connected to an internet network connection. Then, teachers can conduct the learning process at the same time using groups on social media such as Whatsapp (WA), telegram, Zoom application or other social media as a learning tool so that they can ensure that their students learn at the same time even though in different places. Moreover, teachers can also provide structured assignments but they still need to ensure that students learning process is carried out step by step from the task every day.

SMAN 10 Malang, one of the schools in Indonesia, conducts learning from home since the governments' curriculum was announced. Then, Japanese language, one lesson learnt by students in language and science major, is also conducted by online learning. In facing many challenges during online learning from home, the authors of this research made a video about Japanese language learning which was uploaded to YouTube as a media to deliver Japanese language learning materials. Moreover, various applications were also used in online learning, such as Google Classroom, Whatsapp (WA), Padlet, Quizizz, and so on. Meanwhile, for virtual face-to-face purposes, the Zoom application is used. However, to determine the effectiveness of learning, it is needed to have certain preparation either for the school or the teachers. One thing that needs to be carefully prepared is the method of assessment and evaluation of students learning.

According to Bali and Hajriyah, in the escalation of technology in this era of globalization, education is not only required for its functions and roles but also must be transformed with the conditions and challenges in the millennial era [2]. Learning models are conducted by online environment required teachers' creativity and skills to use technology. Students are also expected to be able to access a network of applications used in learning such as Zoom and several other applications. In line with this, Corbi and Burgos stated that online environments usually rely on two fundamental technologies: the online campus and the virtual classroom system [3]. A Learning Management System (LMS) is server-side software responsible for deploying the online campus. LMS can deliver the content needed by complex activities, like virtual laboratories as evinced by the research works described in. The virtual classroom environment (VCE) consists of the digital environment in which educators and students meet in real-time to foster the learning experience. Although it can be a solution to support learning in the midst of the Covid-19 pandemic, there are obstacles they face because other problems arise related to the lack of network access or low of internet connection, the burden of data costs to access expensive applications, the unpreparedness of teachers to adopt technology, parents who are less synergistic with teachers in accompanying children to study at home, and students are emotionally and socially disconnected from other students. Therefore, other alternatives need to be carefully considered to create a good and effective study environment, both for teachers and students in an emergency caused by the Covid-19 pandemic.

Apart from the aspect of learning, another area that needs to be considered in distance learning using this online method is the assessment and evaluation of learning. According to Yusuf, assessment is used to determine the achievement and progress of students in learning and improve the learning process and student activities in learning (assessment of learning and assessment for learning) [4]. Assessment and evaluation of learning in conditions of social distancing and physical distancing carried out at home can use the remote assessment method. With the rapid development and advancement of technology today, the implementation of remote assessment is possible and facilitated, especially with the internet network. Teachers can use application media that are connected to the internet network to conduct online assessments and evaluations of learning outcomes. The assessment can be in the form of quizzes, online tests, individual assignments, or other forms of online assessment using the internet. The selection of the online assessment concept is seen as one of the concepts of learning that provides an opportunity for students to perform critical thinking processes [5]. The assessment carried out needs to give sufficient attention to the aspects of knowledge (cognitive), attitude (affective), and skills (psychomotor) in a balanced way even though the learning is carried out remotely. With the limitations of space and distance, the problem faced by Japanese language teachers at SMAN 10 Malang was skill assessment (psychomotor).

According to Fadillah, assessment on skill in the 2013 Curriculum is taken from the performance value of students using practical assessment, product assessment, project assessment, and portfolio assessment [6]. There are three tools or instruments to measure student performance, namely (1) a checklist, (2) a rating-scale, and (3) a rubric. Practical assessment is an assessment that requires a response in the form of skills to perform an activity or behaviour in the form of 
making a certain product in accordance with the demands of competence. In line with this, Pramana and Putra stated that assessment in the psychomotor Domain is related to skills after a person has obtained certain learning [7].

Research on authentic assessment, especially for this skill aspect, has been carried out by Dewi, Adnyani and Mardani, where the results showed that an assessment of the competency aspects of students' skills has been applied using performance techniques, but there are shortcomings, namely the lack of time allocation for conducting an assessment and difficulties in choosing the instrument and type of assessment according to the subject matter [8]. In line with this, Yonafri and Gani showed that there are problems experienced by students and educators regarding online teaching and learning activities related to the Covid-19 pandemic [9]. This becomes a challenge for educators to attract attention and increase student activity even though the learning process is carried out remotely. Teachers are expected to be able to manage classes online. In addition, research by Fitriana and Aziz showed that most teachers feel that cognitive assessment (knowledge) is easier to do than psychomotor assessment (practice) on productive language skills [10].

During the current pandemic, the problems regarding psychomotor assessment are increasing, because the assessment cannot be carried out directly in the classroom. The existence of learning that is carried out remotely requires an assessment process in the psychomotor domain in more creative ways. To overcome this problem, several alternative learning assessments have been implemented to measure the psychomotor domain. Based on this background, this study will describe the implementation of alternative assessments of online Japanese language learning in the psychomotor domain at SMAN 10 Malang.

\section{METHODS}

The method used in this research is descriptive qualitative. It will describe how the implementation of alternative assessments of Japanese language learning in the psychomotor domain through online learning at SMAN 10 Malang. The primary data collection process was carried out through document review and field data. Then, the sources of data came from 34 students of class X and 33 students of XI languages at SMAN 10 Malang. The analysis was carried out by describing the form of implementation of the Japanese language learning assessment in the online psychomotor domain that had been carried out.

\section{RESULTS AND DISCUSSION}

Several types of alternative assessment in the psychomotor domain for Japanese language learning through online learning have been implemented at SMAN 10 Malang. Students learning outcomes can be grouped into three domains, namely cognitive, affective, and psychomotor. These three domains cannot be separated from each other explicitly. Whatever the subject, it always contains those three domains, but the emphasis of each domain is different. Subjects that require practical skills are more focused on the psychomotor domain, while subjects that require theoretical abilities are more focused on the cognitive domain, and both always contain the affective domain. The assessment of students' skills at SMAN 10 Malang is defined as an assessment carried out to measure the ability of students to apply knowledge in carrying out certain tasks in various contexts according to indicators of competency achievement.

The assessment techniques of students' skills used have been selected according to the characteristics of the Basic Competencies in KI-4, which are stated on K13 (Indonesian education curriculum). The results of learning skills (psychomotor) at SMAN 10 Malang were measured through (1) direct observation and assessment of student behavior during the practical learning process, (2) after participating in learning, namely by giving assignments or tests to students to measure knowledge, skills, and attitudes, and (3) sometime after learning is complete.

The core competencies and basic competencies of Japanese language learning in schools are structured based on the applicable curriculum and aim to achieve four interrelated aspects of language skills, namely listening, speaking, reading, and writing. These skills are also assessed in the psychomotor aspect at SMAN 10 Malang. During the distance learning period, one of the authors of this research as a Japanese language teacher at SMAN 10 Malang, has tried to apply several alternative assessments in the psychomotor domain for assessing Japanese language students. Due to the limitations of distance learning conditions, the most frequently applied skills assessment is for speaking and writing skills. The implementation of psychomotor learning assessment for the Japanese language online learning at SMAN 10 Malang is presented in the following table. 
Table 1. The Implementation of Alternative Assessment in Japanese Language Online Learning at SMAN 10 Malang

\begin{tabular}{|c|c|c|}
\hline $\begin{array}{c}\text { Types of } \\
\text { Psychomotor } \\
\text { assessment }\end{array}$ & No & Type of Assessment \\
\hline \multirow[t]{4}{*}{ Practice } & 1 & $\begin{array}{l}\text { Practice Pair Conversation } \\
\text { Through the Zoom Meeting } \\
\text { application }\end{array}$ \\
\hline & 2 & $\begin{array}{l}\text { Presentation of Essay } \\
\text { Results Orally Through } \\
\text { Voice Note }\end{array}$ \\
\hline & 3 & $\begin{array}{l}\text { Oral Presentation Through } \\
\text { Video }\end{array}$ \\
\hline & 4 & $\begin{array}{l}\text { Short essay writing via } \\
\text { Google Slides }\end{array}$ \\
\hline \multirow[t]{3}{*}{ Product } & 1 & Video \\
\hline & 2 & Essay Manuscript \\
\hline & 3 & Digital flyers and posters \\
\hline \multirow[t]{2}{*}{ Project } & 1 & Journal project assignments \\
\hline & 2 & $\begin{array}{l}\text { Japanese friend project } \\
\text { assignment }\end{array}$ \\
\hline
\end{tabular}

\subsection{Practical Assessment as an Assessment of Japanese Language Online Learning in the Psychomotor Domain}

The implementation of practical assessment for Japanese language learning at SMAN 10 Malang aims to assess students' ability to demonstrate their skills in carrying out certain activities based on learning objectives. Practical assessment is more authentic than paper and pencil assessment because the task forms have better reflection of the students' abilities that are needed in daily life practice.

The implementation of practice assessment as an online assessment of Japanese language learning in the psychomotor domain at SMAN 10 Malang will be described as follows.

\subsubsection{Pair Conversation Practice through the Zoom Meeting Application}

Oral skills must be assessed regularly, especially for students who do not understand enough of language instructions so that students also get good marks in their written assessments. In paired conversations orally, students can respond to questions with certain topics related to science, activities, interests and hobbies, or others submitted by their friends. Meanwhile, teachers can dig up information from students and assess students' skills in responding to various questions by observing and asking questions.

In distance learning, the practice of conversation in pairs at SMAN 10 Malang is done through the Zoom application. After students practice conversation, the teacher will ask additional questions related to the content of the conversation to check the students' understanding.

\subsubsection{Oral Presentation of Writing Results through Voice Notes}

Another alternative speaking practice for students was having a presentation of their essays that had been compiled. In learning the conventional system, students were asked to do a presentation one by one in front of the class after compiling an essay. In distance learning or online learning, the presentation could be circumvented by using the voice note feature on the cell phone. These recordings were then uploaded via the Google Classroom application or Padlet

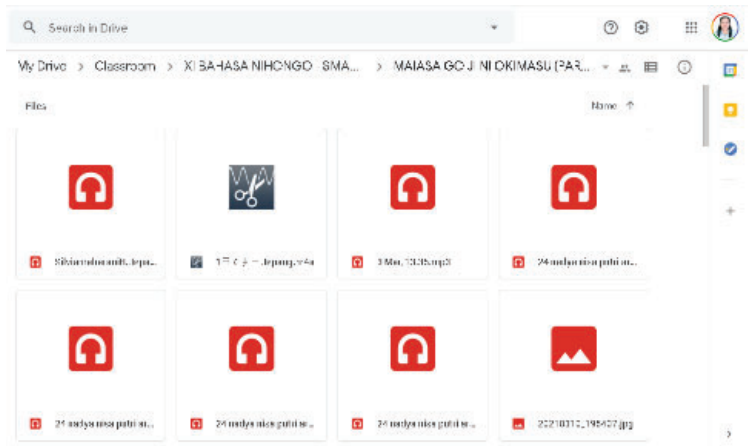

Figure 1 Oral presentation results through voice Notes in Google drive

\subsubsection{Oral Presentation through Video}

The Voice note feature could be used when the teacher wanted to assess whether the students' Japanese pronunciation is correct or not. However, if the teacher wanted to assess the students' expressions in speaking, then video could be the solution. After the video was made by students, the video could be uploaded via the Google Classroom application, YouTube or Instagram. 


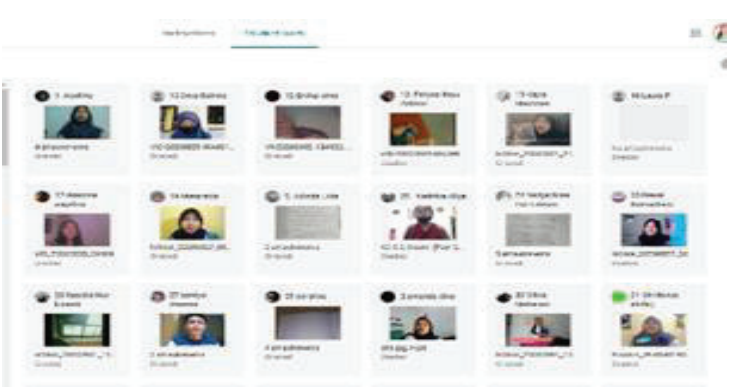

Figure 2 Oral presentation through video collected through Google Classroom

\subsubsection{Writing a Short Essay via Google Slides}

Besides, speaking aspect, the practical assessment that could also be implementation in writing. The mechanisms were: the teacher provided work instructions to students through Google Classroom, the teacher provided a Google Slides link to students, students wrote their short essay on Google Slides and at the end of the assessment, the teacher checked the students' work. During the zoom meeting, the results of these student essays could be discussed together for feedback from the teacher.

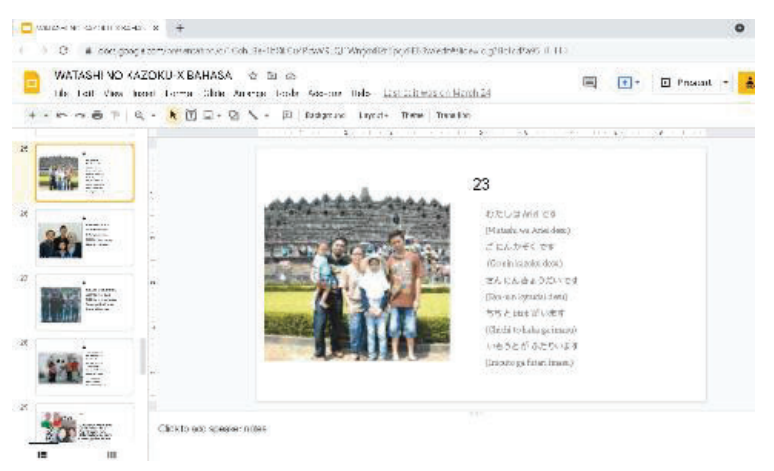

Figure 3 Writing a short essay through Google Slides

\subsection{Product Assessment as an Assessment of Japanese Language Online Learning in the Psychomotor Domain}

Product assessment for Japanese language learning at SMAN 10 Malang aims to (1) assess students' skills in making certain products in relation to achieving Japanese language learning objectives; (2) assessing mastery of skills as a condition for learning skills in the next Japanese language material; and (3) assessing the ability of students to explore and develop ideas in designing and demonstrating their innovations and creations related to learning Japanese.

The implementation of product assessment as an online assessment of Japanese language learning in the psychomotor domain at SMAN 10 Malang is as follows.

\subsubsection{Video}

In addition, to being assessed for speaking practice, the results of student work in the form of videos could be assessed as product assessments. The students' video recorded speaking tasks and assigned as a homework. The video could be uploaded via the Google Classroom application, Youtube or the student's personal Instagram account.

\subsubsection{Essay Manuscript}

Students' writing skills could be assessed through essays prepared by students. This manuscript was compiled after receiving instructions for processing in Google classroom, written on a sheet of paper and decorated as creatively as possible, then uploaded through the Google Classroom and Padlet applications. The criteria for self-assessment could be seen from two aspects, namely the content of the essay and the creativity of students in decorating the results of their essays.

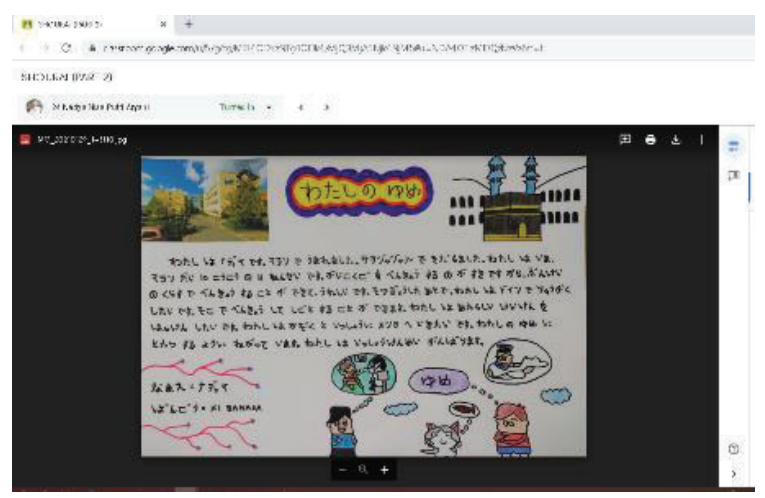

Figure 4 Example of student work essay

\subsubsection{Pamphlet and Poster Digital}

For certain themes such as tourism, students could be assessed through the creation of digital pamphlets and posters. Digital pamphlets dan posters are used as an alternative teaching strategy to improve students' creativity and understanding on another concept that require students to share their knowledge and develop their creativity. The results of the product could be uploaded via Google Classroom, Instagram and Padlet applications. 


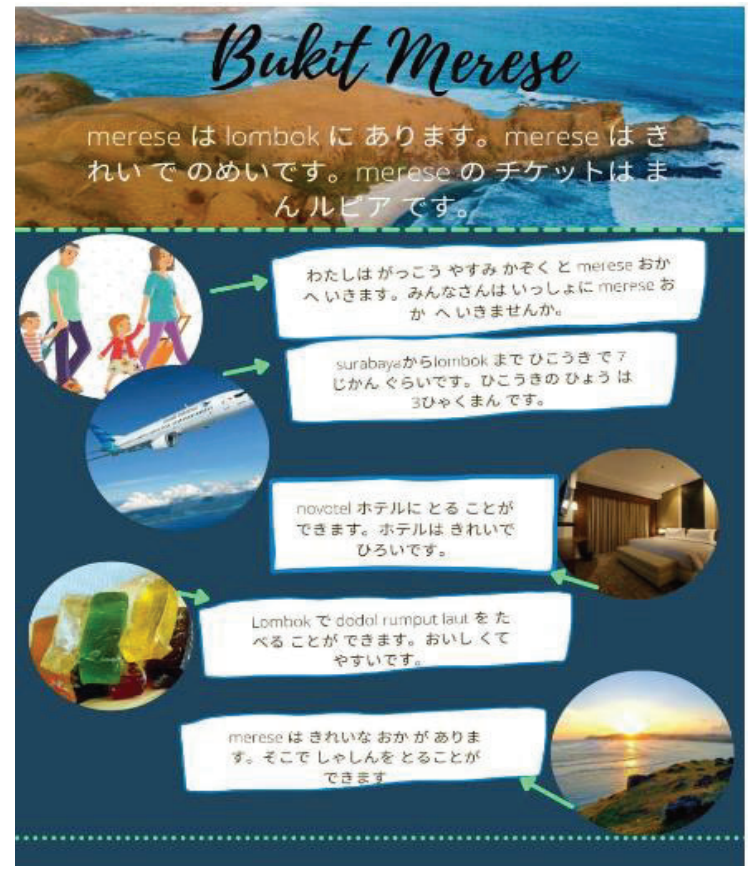

Figure 5. Example of a digital pamphlet of students' work

\subsection{Project Assessment as an Assessment of Japanese Language Learning in the Psychomotor Domain Online}

Project assessment aims to develop and monitor students' skills in planning, investigating, and analyzing projects. In this context, students could demonstrate their experience and knowledge of a topic, formulate questions and investigate the topic through reading, tours and interviews. Then, their activities could be used to assess their ability to work independently or in groups. The product of a project could be used to assess the ability of students to communicate their findings in an appropriate form, for example the presentation of results through visual displays or written reports. The scoring could be done using a rubric scale or numerical assessment.

The implementation of project assessment as an online assessment of Japanese language learning in the psychomotor domain at SMAN 10 Malang is as follows.

\subsubsection{Journal Project Tasks}

The task of the journal project was to write a simple journal in the form of a themed essay for 1 semester. The topic of this essay changes every month. Before uploading, students had the opportunity to consult with the teacher. After feeling good, then this themed essay was written on a sheet of paper, and decorated or illustrated according to the contents of the essay. It is because one journal was done every month, then at the end of the semester, there would be six journals collected.

The collection could be done via Google Drive, where students already have their own folders.

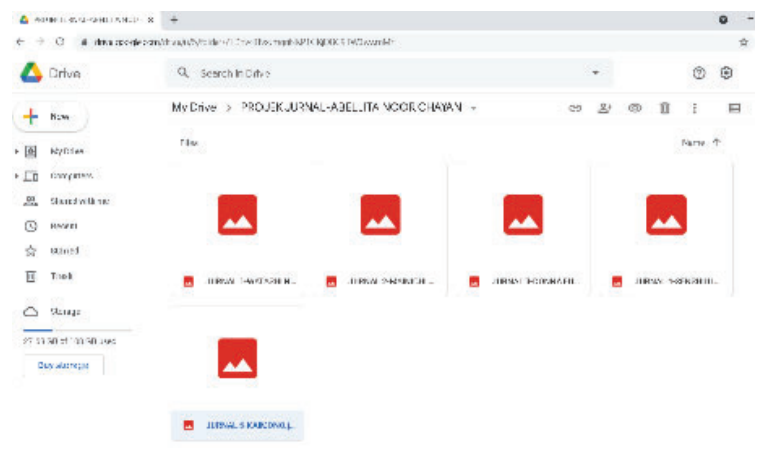

Figure 6. Examples of journals uploaded by students on Google Drive

\subsubsection{Japanese Friends Project Assignments}

In this research, the task of the Japanese friend project was to invite Japanese people to talk through social media such as Instagram and hello talk. Talking means sending messages to each other through social media. The topic of the content of this talk changes every month. Every time you complete a topic, the results of this conversation are then captured and pasted in the task sheet format that had been prepared by the teacher, which is in MS words. Like journals, this Japanese friend's project report was collected via Google Drive, where students already have their own folders.

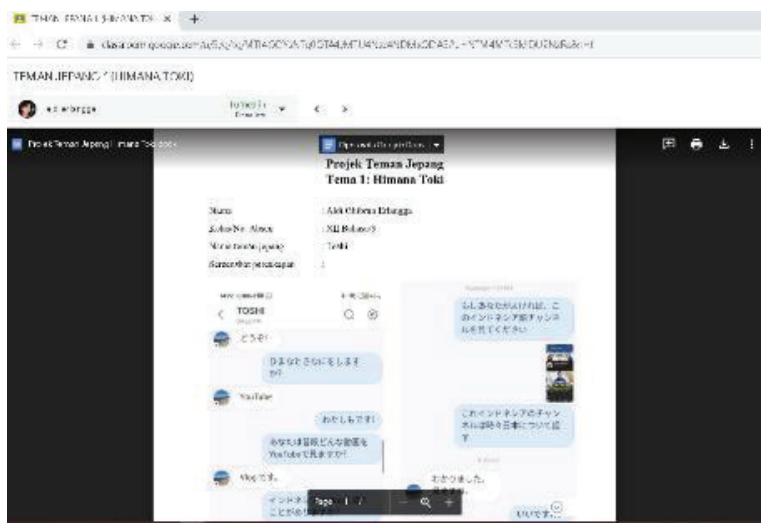

Figure 7. Examples of Japanese Friends Projects Uploaded by Students on Google Drive 
This online psychomotor assessment at SMAN 10 Malang, in its implementation, it has several stages, namely:

1) Assessment planning;

2) Preparation of assessment instruments;

3) Implementation of the assessment;

4) Utilization of assessment results; and

5) Reporting the results of the assessment in the form of numbers with a scale of $0-100$ and supported by the description obtained from the portfolio results.

The assignments, which were given to measure psychomotor abilities, were also adjusted to certain criteria, among others, leading to the achievement of learning outcomes indicators; can be done by students; could be done during the learning process or is part of independent learning; according to the level of development of students; contains material that was in accordance with the scope of the curriculum; fair (not biased by gender and socio-economic background); and included the time span for the task. With clear criteria and instructions, problems that arose during online psychomotor assessment could be reduced or eliminated. Teachers should also pay attention to the workload given so that students were happy to learn even from home and also avoid stress.

Some previous findings by Dewi; Adnyani and Mardani; and Fitriana and Aziz stated that psychomotor assessment was considered more difficult due to the lack of time allocation for conducting the assessment and to some difficulties in choosing the appropriate instrument and type of assessment. In addition, Yonafri and Gani also stated that the Covid 19 pandemic was a problem experienced by students and educators regarding online teaching and learning activities particularly in the field of assessment. Through this research, we can see that the problems aroused in the previous studies can be resolved as there are several alternative psychomotor assessments which can be applied to online Japanese language learning. The assessment process and the types of instruments can be adapted to the students' needs. The current pandemic should not be the reason for teachers or educators to not be passionate about teaching, innovating, and igniting students' learning enthusiasm.

\section{CONCLUSION}

Based on a case study that has been conducted at SMAN 10 Malang during learning from home, it can be concluded that several alternative assessments in the psychomotor domain have been implemented in online learning of Japanese language learning, including online practice, product and project assessments. The implementation of those alternative assessments has overcome the problem of psychomotor assessment during the pandemic faced at SMAN 10 Malang.

In order to achieve success in psychomotor assessment in distance learning, the teachers should give assignments in various ways so that students do not feel bored. The implementation of psychomotor assessment should also be strengthened by reflection through virtual face-to-face through online face-to-face applications such as Zoom Meeting, Google Meet or others. Further research is needed to determine the effectiveness of the implementation of alternative Japanese language learning assessments in the online psychomotor domain.

\section{REFERENCES}

[1] S. Wang, N. P. Bajwa, R. Tong, and H. Kelly, Transitioning to Online Teaching. In Radical Solutions for Education in a Crisis Context. Singapore: Springer, 2021.

[2] M. M. E. I. Bali and H. B. Hajriyah, "Modernisasi Pendidikan Agama Islam Di Era Revolusi Industri 4.0," MOMENTUM J. Sos. dan Keagamaan, vol. 9, no. 1, pp. 42-62, 2020, doi: 10.29062/mmt.v9i1.64

[3] A. Corbi and D. Burgos, From Classroom to Online Lessons: Adapted Methodology for Teachers. In Radical Solutions for Education in a Crisis Context. Singapore, 2021.

[4] A. M. Yusuf, Asesmen dan Evaluasi Pendidikan. akarta: Kencana, 2017.

[5] C. Muali, S. Islam, M. E. I. Bali, H. Hefniy, H. Baharun, A. Mundiri, M. Jasri, and A. Fauzi, "Free Online Learning Based On Rich Internet Applications; The Experimentation Of Critical Thinking About Student Learning Style," J. Phys. Conf. Ser., vol. 1114, pp. 1-6, 2018.

[6] M. Fadillah, Implementasi Kurikulum 2013 Dalam Pembelajaran SD/MI, SMP/MTs, \& SMA/MA. Yogyakarta: Ar-ruzz Media, 2014.

[7] K. A. B. Pramana and D. B. K. N. S. Putra, Merancang Penilaian Autentik. Bali: CV. Media Education, 2019.

[8] K. A. K. Dewi, K. E. K. Adnyani, and D.M.S.Mardani, "Implementasi Penilaian 
Autentik Oleh Guru Bahasa Jepang Di Kelas X SMA Laboratorium Undiksha Singaraja," JPBJ, vol. 5, no. 2, pp. 286-294, 2019.

[9] C. Yonafri and E. Gani, "The Effectiveness of Online Learning on the Implementation of the 2013 Curriculum," Proc. Ninth Int. Conf. Lang. Arts (ICLA 2020), vol. 539, no. Icla 2020, pp. 246250, 2021, doi: 10.2991/assehr.k.210325.044.

[10]F. Fitriana, F. Trisna, A. Aziez, "Pengetahuan Dan Persepsi Guru Bahasa Indonesia Smk SeKabupaten Banyumas Tentang Evaluasi Pembelajaran Keterampilan Berbahasa Produktif Dalam Kurikulum 2013," Metafora, vol. 7, no. 1, pp. $15-29,2020$ 